\title{
Identification of priority habitats for conservation of the Sierra Madre sparrow Xenospiza baileyi in Mexico
}

\author{
Leonardo Cabrera-García, José Alejandro Velázquez Montes and Martha Elena Escamilla Weinmann
}

\begin{abstract}
The Sierra Madre sparrow Xenospiza baileyi, categorized as Endangered on the IUCN Red List, is endemic to Mexico. The subalpine bunch grasslands of the Transverse Volcanic Belt in the south of the Valley of Mexico are the last remaining habitat of this species. We conducted a detailed survey for the Sierra Madre sparrow using the point count method, and then described the species' habitat using a phytosociological approach. The two sets of information were pooled into a single analytical framework to identify priority habitats for the species. Eight vegetation communities were distinguished. The Festuca lugens-Muhlenbergia quadridentata and Stipa ichu bunch grassland communities had the highest densities of the Sierra Madre sparrow. Intensive
\end{abstract}

burning and grazing activities and agricultural encroachment have restricted sparrow occupancy. Landscape analysis helped to delineate core grassland areas for the species and grassland strips and islands that could potentially act as habitat corridors. From the information generated in this study, which was shared with the local communities, we are establishing a participatory socioecological investigation for conservation of the Sierra Madre sparrow's habitat.

Keywords Festuca lugens, grassland birds, Mexico, Milpa Alta, San Juan Tlacotenco, Xenospiza baileyi.

This paper contains supplementary material that can only be found online at http:/ /journals.cambridge.org

\section{Introduction}

Habitat loss and fragmentation are recognized as the main threats to biodiversity (Mayr, 2000), and innovative, participatory and adaptive methods are urgently required to slow down the loss of species (Velázquez et al., 2003). The endemic Mexican Sierra Madre sparrow Xenospiza baileyi (Bangs, 1931) is known only from Sierra Madre Occidental (the high mountains of southern Durango and northern Jalisco) and the south-central Transverse Volcanic Belt (in the Distrito Federal-Morelos Estate; Collar et al., 1992; Cabrera, 1999). The northern range of the species' habitat has been transformed into agricultural lands and therefore the subalpine bunch grasslands of the Transverse Volcanic Belt are the last remaining habitat for Xenospiza baileyi (Cabrera \& Navarro-Sigüenza, 2000). Areas of subalpine bunch

Leonardo Cabrera-García* (Corresponding author) Laboratorio de Biogeografía, Facultad de Ciencias, UNAM, Circuito Exterior s/n., Ciudad Universitaria, Ciudad de México, México. E-mail Icabre@po-box.mcgill.ca

José Alejandro Velázquez Montes Unidad Académica de Geografía, Instituto de Geografía, UNAM, Aquiles Serdán 382, Morelia Michoacán 58000, México.

Martha Elena Escamilla Weinmann Comisión Nacional para el Conocimiento y Uso de la Biodiversidad en México, Mexico.

${ }^{*}$ Current address: Department of Geography, McGill University, 805 Sherbrooke Street West, Montreal, Quebec, H3A 2K6, Canada.

Received 1 June 2004. Revision requested 9 September 2004. Accepted 7 March 2005. grassland have been reduced by $50 \%$ in the last 10 years (Cabrera, 1999; Velázquez \& Romero, 1999; González, 2000) and are fragmented and disturbed as a consequence of agricultural encroachment (mainly cultivation of oats and potatoes), intensification of livestock production, inappropriate fire management, exotic tree plantations, and urban expansion of Mexico City.

Most studies of the Sierra Madre sparrow have concerned its taxonomy, distribution and natural history (Pitelka, 1947; Dickerman et al., 1967; Oliveras de Ita et al., 2001) and mostly in only one locality, La Cima, near Mexico City. La Cima was previously considered to be the only site inhabited by the Sierra Madre sparrow (Wilson \& Ceballos-Lascurain, 1993), although there had not been a systematic survey for the species. Because of the limited availability of suitable habitat, the Sierra Madre sparrow is both a high conservation and research priority (BirdLife International, 2000). Inappropriate management is causing a continuing and rapid decline and it is therefore categorized as Endangered on the IUCN Red List (IUCN, 2004). Here we present the results of a detailed survey for the Sierra Madre sparrow, describe its habitat, and present a landscape analysis for the prioritization of conservation areas for the species.

\section{Study area}

The altitude of the southern Valley of Mexico is 2,950 3,600 m (Velázquez \& Romero, 1999; Fig. 1). Climate is temperate, sub-humid, mild to cool, with a mean annual 


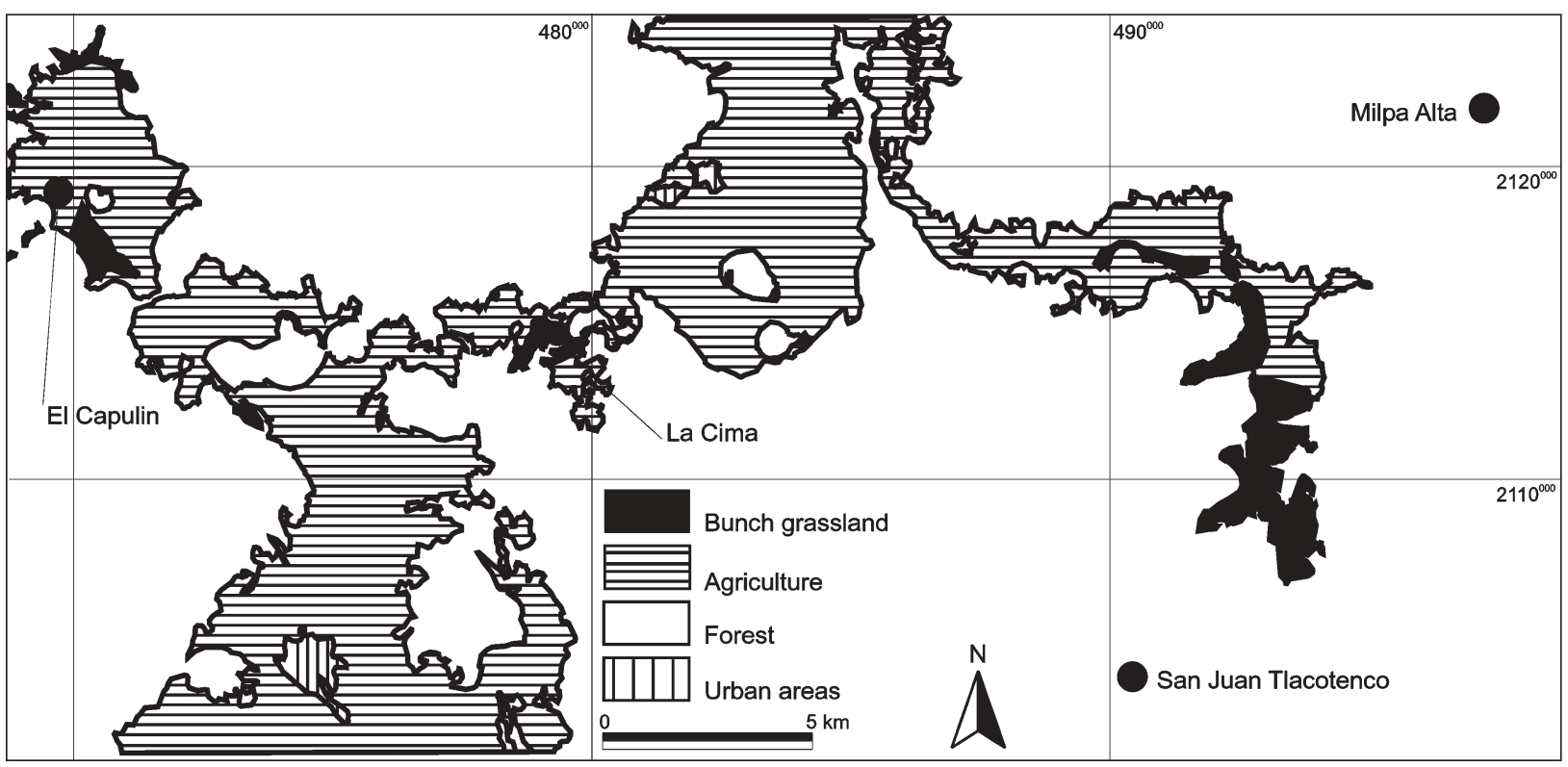

Fig. 1 The study area in the southern Valley of Mexico, with location of bunch grasslands and other land cover types.

temperature of $c \cdot 16^{\circ} \mathrm{C}$ and a mean annual rainfall of c. $800 \mathrm{~mm}$. The area has c. 3,000 plant and 350 vertebrate species (Fa \& Morales, 1993; Velázquez \& Romero, 1999). Subalpine bunch grasslands or zacatonales (the regional vernacular name of bunch grassland) are restricted to flat valley bottoms with little or no tree cover (Rzedowski, 1978). Land tenure on the zacatonales is principally communal. Traditional governance institutions regulate access and use of natural resources for community members. Main land uses and managerial practices are livestock grazing (cows and sheep). Grasslands have traditionally been burned by local herders to produce fresh pasture. The communities also rely on the grasslands for mushrooms, medicinal plants, and materials for construction and craft products for sale and trade.

\section{Methods}

\section{Estimates of Sierra Madre sparrow abundance}

We systematically surveyed the whole southern region of the Valley of Mexico $\left(>1,000 \mathrm{~km}^{2}\right)$ in the summer of 1998 to determine the occurrence of the Sierra Madre sparrow. The abundance of the Sierra Madre sparrow was estimated using the fixed-radius point count method (sensu Hutto et al., 1986) in a total of 120 plots. Plots were located in a net-like design, $200 \mathrm{~m}$ apart, and surveyed from sunrise until 10.00 in all directions (sensu Freemark \& Rogers, 1995), avoiding extremely rainy or windy days. All plots were geo-referenced. Vocalizations of the Sierra Madre sparrow within a plot were taken as evidence of the species' presence. The total number of individual birds observed or heard and mean bird abundance per plot in each vegetation community (see below) were used to define the habitat of the Sierra Madre sparrow, following Freemark \& Rogers (1995), Velázquez (1993), Velázquez \& Heil (1996) and Huff et al. (2000).

\section{Vegetation survey}

In areas where we located the Sierra Madre sparrow we carried out vegetation surveys, from September 1998 to September 1999, using the phytosociological method of Braun-Blanquet (1932), modified for this type of survey (Velázquez, 1993). A stratified random strategy was used to sample all distinctive plant communities (subalpine grasslands, agricultural fields and pine forest). Relevés were established on identifiable grassland units following homogeneity criteria (Velázquez, 1993). In total 68 relevés were surveyed (Müeller-Dombois \& Ellenberg, 1974). The number of relevés per physiognomic type varied in accordance with the proportional area occupied and the species richness accumulation criteria (Velázquez, 1993). The relevés were $10 * 10 \mathrm{~m}$ in all plant communities, with the exception of some linear grassland remnants, where the size was c. $42 \mathrm{~m}^{2}$. In each relevé the following data were gathered: a complete list of the vascular plant species, an estimation of the percentage cover of each species, of rock, litter, bare ground, and of each vegetation layer. All habitat disturbance factors (grazing, burning and trampling) were noted. Grazing was considered to be present if traces were seen. Burning was considered to be present if ash traces were found in the vegetation or on the ground. Trampling was considered to be present if soil had cow or sheep footprints 
and/or there was evidence of compacted soil. The location of each relevé was determined with a global positioning system. Vascular plant specimens were identified and deposited in the Herbarium Agustína Batalla (FCME, UNAM, México, D.F.).

\section{Landscape analysis}

A set of 25 aerial photographs (1997; scale 1:35,000) was interpreted to delineate land cover types, following Haines-Young et al. (1993). From the aerial photographs we drew a geo-referenced and oriented photo mosaic, which we ground-truthed by noting the position of three identifiable landscape elements (e.g. road intersection, field edge or other topographic feature) per photograph using a global positioning system. Three main physiognomic vegetation types were identified in the photographs: subalpine bunch grassland, agricultural fields and pine forest. The phytosociological relevé positions were linked to the physiognomic types to construct a vegetation map (sensu Velázquez, 1993). The final vegetation map, produced with the geographical information system ArcView 3.2 (ESRI, Redmond, USA) included forest cover, bunch grassland, agriculture and human settlements. All fixed-radius point count plots of the Sierra Madre sparrow (see above) were pooled into three abundance categories according to the total number of individuals observed: high ( $>40$ individuals), medium (1-39) and absent. These layers were overlain on the vegetation map, which was then used to delineate key areas for conservation.

\section{Statistical analysis}

Two-way indicator species analysis (TWINSPAN; Hill, 1979; Hill \& Gauch, 1980; McCune \& Mefford, 1995) was used to define plant communities. To examine the assemblage of plant species defining each plant community the relevés and species were sorted and arranged into a phytosociological table (Braun-Blanquet, 1932). Data on physiognomy, species composition, disturbance and ecology were used to characterize each plant community.

A Canonical Correspondence Analysis (CCA) was performed on the phytosociological table to examine the environmental variables that influence the distribution of the plant communities (ter Braak, 1987; McCune \& Mefford, 1995) and therefore the distribution of the sparrow (sensu Velázquez \& Heil, 1996). The number of sparrows recorded in the fixed-radius point count plots in each plant community was pooled and a KruskalWallis test used to determine whether the total number of individuals differed between plant communities. Differences were validated using resampling procedures (Mooney \& Duval, 1993; Davidson \& Hinkley, 1997), following recommendations from other bird studies (Huff et al., 2000; Lusk et al., 2003). We computed mean Sierra Madre sparrow abundance per survey plot and 95\% confidence intervals from 1,000 resampling iterations using the software Pop Tools (Hood, 2003).

\section{Sharing information at the local level}

Milpa Alta and San Juan Tlacotenco local community key members and local environmental authorities were contacted at the beginning of the study to inform them about the conservation status of the Sierra Madre sparrow and about our research. Results from our study, such as key areas for sparrow conservation, species' habitat preferences and habitat impacts from current land use practices were communicated in summer 2001 to local stakeholders using a variety of participatory techniques (Mukherjee, 1993) such as talks, meetings and field trips.

\section{Results}

The Sierra Madre sparrow's habitat can be defined as a mosaic of subalpine bunch grassland communities and man-made land cover types such as crops. A total of 169 vascular plant species were recorded (Appendix). Physiognomically, the Sierra Madre sparrow habitat can be described as semi-open bunch grassland of $1 \mathrm{~m}$ in height and with spikes taller than $2 \mathrm{~m}$ (Plate 1). Grassland cover is $5-95 \%$ depending on land use intensity. Litter covers c. $5 \%$ of the ground, whereas shrubs and trees are poor and scarcely represented in the sparrow's habitat. The main disturbance variables identified in the grasslands were fire evidence, trampling and grazing, with 90, 15 and $10 \%$ cover, respectively, within the whole region.

Eight plant communities were delimited within the Sierra Madre sparrow's current range. The attributes and differences that characterize each community are given in Table 1, and the floristic composition of each community in the phytosociological table (Appendix). The total

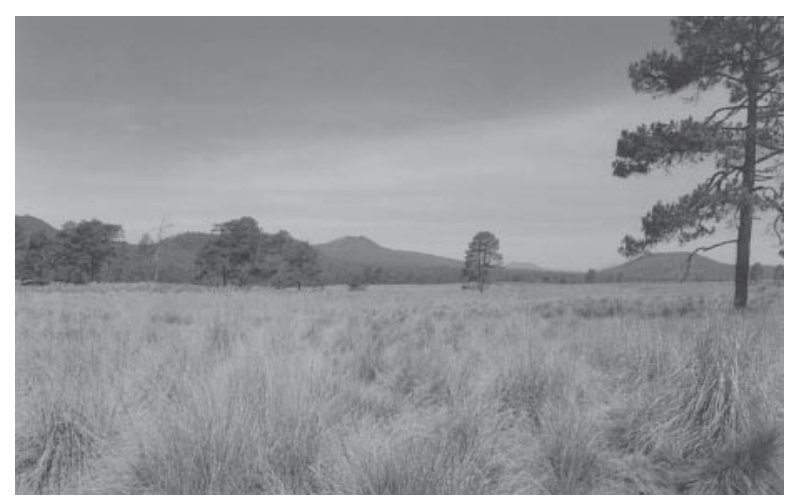

Plate 1 Typical Sierra Madre sparrow habitat. L. Cabrera-García, 2001. 


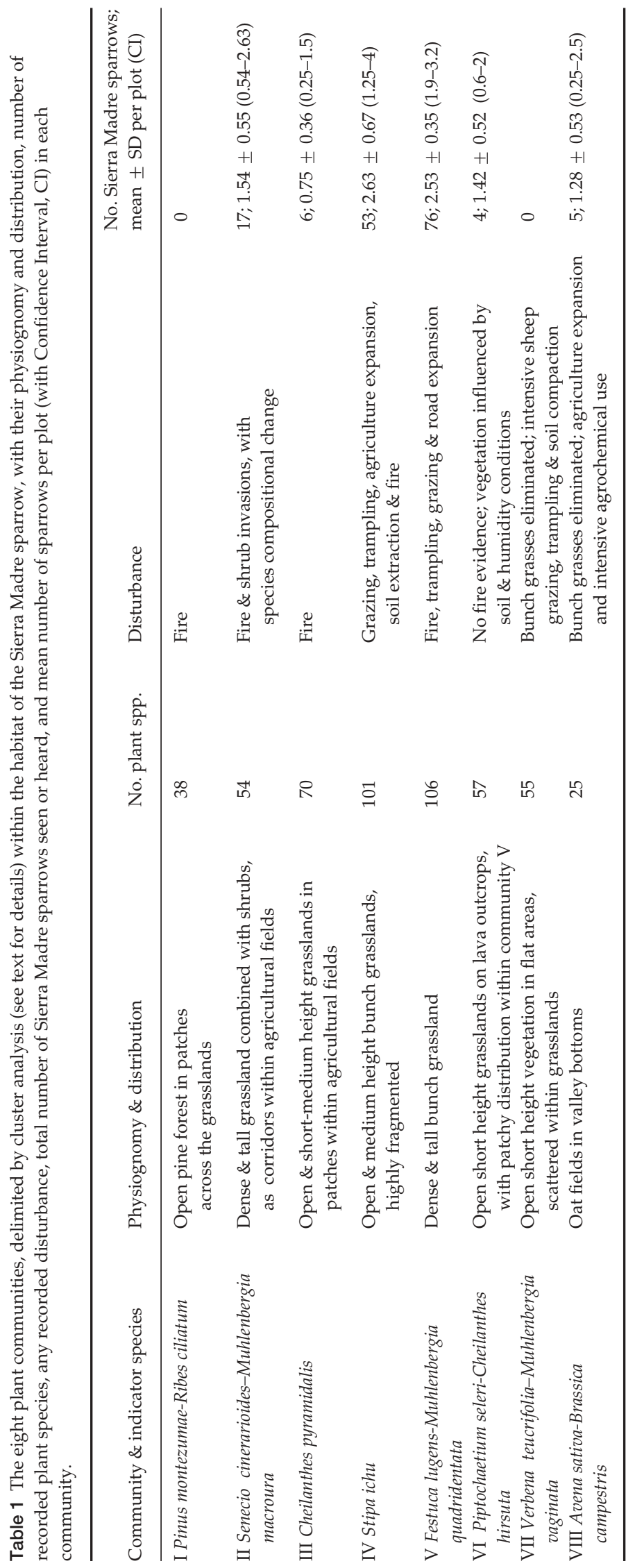


number of sparrows observed varied significantly between plant communities $\left(\chi^{2}=17.10, \mathrm{df}=7, \mathrm{P}=0.01\right)$. The most important plant communities for the sparrow, i.e. those in which the greatest number of sparrows were observed and that had the highest mean bird density per point count plot, were Festuca lugens-Muhlenbergia quadridentata (Community IV) and Stipa ichu (V). The Sierra Madre sparrow was rarely found within other bunch grassland plant communities (Table 1). Only five individuals were recorded in the Avena sativa-Brassica campestris community (VIII), and the species was absent from the Pinus montezumae-Ribes ciliatum (I) and Verbena teucrifolia communities (VII). The sparrow avoided sites of intensive grazing, particularly those transformed into grazing prairies with little or no bunch grass coverage.

Canonical correspondence analysis (Fig. 2) indicated a good segregation of the plant communities. The first two axes accounted for $58 \%$ of the total variance. Axis 1 differentiated the bunch grassland communities from agricultural landscapes. Plant species richness and fire were the variables most strongly related to this axis $(r=0.69$ and $r=0.66$, respectively). Axis 1 also indicates a gradient within the grassland communities, from richest and continuous bunch grassland areas to less diverse and highly fragmented grassland patches. Communities IV

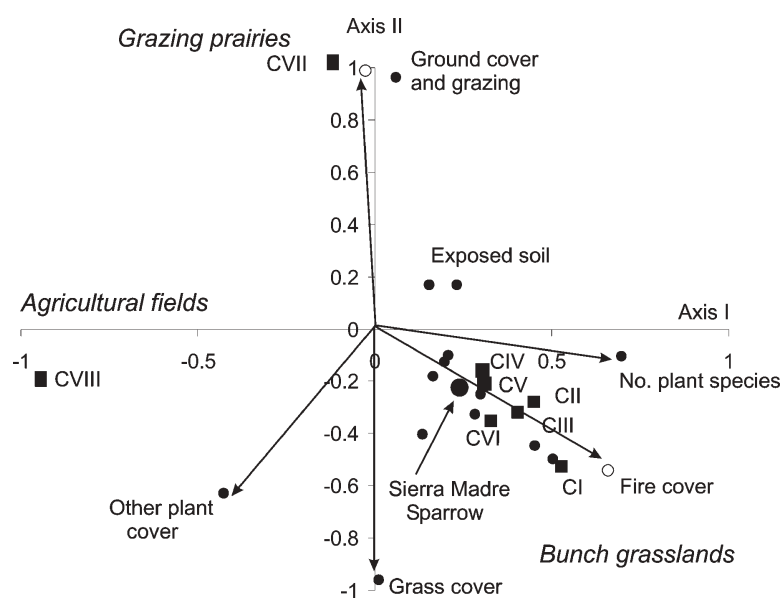

Fig. 2 Ordination diagram produced by canonical correspondence analysis of the phytosociological table (Appendix) showing the eight vegetation communities and variation in habitat structure. Sierra Madre sparrow coordinates represents bird species habitat preferences. Vegetation communities (Table 1) are: I, Pinus montezumae-Ribes ciliatum; II, Senecio cinerarioides-Muhlenbergia macroura; III, Cheilanthes pyramidalis; IV, Stipa ichu; V, Festuca lugens-Muhlenbergia quadridentata; VI, Piptochaetium seleriCheilanthes hirsuta; VII, Verbena teucrifolia-Muhlenbergia vaginata; VIII; Avena sativa-Brassica campestris. Environmental variables that significantly explain $(\mathrm{P}<0.01)$ variation in the data are indicated at the end of each arrow, the length of which is proportional to the degree of influence of each variable. Eigenvalues are: Axis I $=0.778$ (accounting for $33 \%$ of the variation in the data), Axis II $=0.586$ (accounting for $25 \%$ of the variation in the data). and $\mathrm{V}$, with the highest sparrow densities, were the richest and most continuous grassland areas. Disturbance variables other than fire were significantly correlated with Axis 2 (grazing cover $r=0.98$, ground plant cover $r=0.96)$.

Community IV occurs mainly in the Milpa Alta-San Juan Tlacotenco lands where the largest area of continuous bunch grassland remains. Community V predominates in reduced, disturbed and fragmented patches, mainly at La Cima and El Capulin. Communities II (Senecio cinerarioides-Muhlenbergia macroura) and III (Cheilanthes pyramidalis) are grassland remnants distributed mostly in the northern area where agriculture and road expansion have displaced grassland types. Community VI (Piptochaetium seleri-Cheilanthes hirsuta) occurs on prominent lava outcrops embedded in the plains covered by bunch grasses of Community IV.

By looking at the spatial distribution of vegetation communities and the abundance of the Sierra Madre sparrow three main series of areas were identified as priorities for the sparrow's conservation: (1) the grasslands in Milpa Alta-San Juan Tlacotenco (Community V), (2) the patches in La Cima and El Capulin (Community IV), and (3) the grassland strips (Community II) and grassland islands (Community III). The latter two are important because of their potential to act as corridors to connect the Sierra Madre sparrow populations of Milpa Alta to La Cima and El Capulin.

\section{Discussion}

The habitat of the Sierra Madre sparrow is the last remnant of the typical subalpine bunch grasslands of the southern Valley of Mexico (Rzedowski, 1978; Cabrera, 1999). The description provided here of the grassland areas occupied by the Sierra Madre sparrow broadens the conservation possibilities for the species. Our survey also demonstrates the strong relationship between a specific grassland type and the abundance of this sparrow.

The Sierra Madre sparrow has a strong affinity for the Festuca lugens-Muhlenbergia quadridentata and Stipa ichu communities. F. lugens is one of the tallest grass species in the region, with a dense cover $(>80 \%)$ and occupying large areas. It is a key requirement for Sierra Madre sparrow reproduction (L. Cabrera-García \& G. Seutin, unpubl. data). The Milpa Alta-San Juan Tlacotenco communal lands may represent the last core area of this grass species in the central part of Mexico and, as a consequence, the last refuge of any significant size for the Sierra Madre sparrow. Although activities such as soil extraction, overgrazing and agriculture expansion have displaced native grass species in the Stipa ichu community, there is evidence that the sparrow still breeds there (Oliveras et al., 2001). 
Communities II, III and VI are also important because they include bunch grass species that make them suitable for the Sierra Madre sparrow. Both structurally (the presence of bunch grass species) and spatially (their location and arrangement), these communities may play an important role in the population dynamics of the Sierra Madre sparrow in this heterogeneous landscape (Haire et al., 2000; Bajema \& Lima, 2001; Fletcher \& Koford, 2002).

The elimination of bunch grasses during the creation of new agricultural fields, or their progressive elimination through excessive fires, contribute to the degradation and disappearance of this unique ecosystem and its associated endemic species. Because local land use practices have shaped this ecosystem and because of the communal tenure system of the zacatonales, an integrative and participative grassland co-management perspective has been recommended to promote the maintenance of this ecosystem and at the same time ensure continuation of local livelihoods (Berkes, 2004; Cabrera \& Frias, 2004; Roe \& Elliott, 2004; Castillo et al., 2005).

From the information generated in this study, which was shared with the local communities of Milpa Alta and San Juan Tlacotenco, we are establishing a participatory socio-ecological investigation for conservation of the Sierra Madre sparrow's habitat. Preliminary findings (L. Cabrera-García, unpubl. data; Cabrera \& Frias, 2004) indicate that herders from these villages have traditional ecological knowledge (sensu Berkes et al., 2000) for local grassland management and conservation. Fire is set in the Milpa Alta-San Juan Tlacotenco communal lands in rotation every $2-3$ years to create a mosaic of grassland conditions (recently burned, 1 year of post-fire recovery, and $>2$ years without fire) that offers green pasture for active use whilst other grassland recovers. Thus, the influence of fire on the distribution of the Sierra Madre sparrow and the grasslands may reflect the effects of this management practice in the maintenance of the grassland community across the entire landscape. An appropriate fire co-management programme within social, spatial and temporal frameworks must be a priority action, in coordination with local communities, to preserve, restore and maintain this ecosystem and its associated traditional land use practices.

\section{Acknowledgements}

The project was financed by CONABIO (R-108) and UNAM (IN212003). The authors thank Aurora Chimal for botanical support. Mario Pinto, Tammo Hoeksemma and Marta Gual helped with the field work. Special thanks to Mardocheo Palma and Charlotte González for their assistance with the digital maps, to Reto Schmucki for advice on resampling theory and techniques, and to the Laboratorio de Biogeografia (Facultad de Ciencias,
UNAM) for facilitating the development of this project. Danielle Donnelly and Mike McCall kindly improved the English grammar. Special recognition is given to the local people of the zacatonales, without whom this research would not have been possible.

\section{References}

Bajema, R. \& Lima, S. (2001) Landscape-level analyses of Henslow's sparrow (Ammodramus henslowii) abundance in reclaimed coal mine grasslands. American Midland Naturalist, 145, 288-298.

Bangs, O. (1931) A new genus and species of American buntings. Proceedings of the New England Zoological Club, XII, 85-88.

Berkes, F. (2004) Rethinking community-based conservation. Conservation Biology, 18, 621-630.

Berkes, F., Colding, J. \& Folke, C. (2000) Rediscovery of traditional ecological knowledge as adaptive management. Ecological Applications, 10, 1251-1262.

Birdlife International (2000) Threatened Birds of the World. The Official Source for Birds on the IUCN Red List. BirdLife International, Cambridge, UK and Lynx Editions, Barcelona, Spain.

Braun-Braunquet, J. (1932) Plant Sociology. The Study of Plant Communities. Stechert-Hafner Service Agency, New York, USA.

Cabrera, L. (1999) La avifauna del sur del Valle de México: aplicación de un enfoque sinecológico-paisajístico para su conservación. MSc thesis, UNAM, México.

Cabrera, L. \& Frias, G. (2004) Facing bird conservation in conflicted communal lands: a participatory experience towards Sierra Madre sparrow habitat conservation. Tenth Biennial Conference of the International Association for the Study of Common Property, Oaxaca, México. Http:/ / www.iascp2004.org.mx/index_eng.html [accessed 23 June 2005].

Cabrera, L. \& Navarro-Sigüenza, A. (2000) Gorrión Serrano. In Las Aves de México en Peligro de Extinción (eds G. Ceballos \& L. Marquez), pp. 314-316. UNAM, FCE, México.

Castillo, A., Torres, A., Bocco, G. \& Velázquez, A. (2005) The use of ecological science by rural producers: a case study in Mexico. Ecological Applications, 15, 745-756.

Collar, N.J., Gonzaga, L.P., Krabbe, N., Madroño, A., Naranjo, L., Parker III, T. \& Wege, D. (1992) Threatened Birds of the Americas. Third Edition, Part 2. Smithsonian Institute Press, Washington, USA and International Council for Bird Preservation, London, UK.

Davidson, A. \& Hinkley, D. (1997) Bootstrap Methods and Their Applications. Cambridge University Press, Cambridge, UK.

Dickerman, W., Phillips, A.R. \& Warner, D.W. (1967) On the Sierra Madre sparrow, Xenospiza baileyi, in Mexico. The Auk, 84, 49-60.

Fa, J. \& Morales, L.M. (1993) Mammals of Mexico: prioritizing diversity. In Biological Diversity of México: Origins and Distribution (eds T.P. Ramamoorthy, R. Bye, A. Lot \& J. Fa), pp. 319-361. Oxford University Press, New York, USA.

Fletcher, R. \& Koford, R. (2002) Habitat and landscape associations of breeding birds in native and restored grasslands. Journal of Wildlife Management, 66, 1011-1022.

Freemak, K. \& Rogers, C. (1995) Modification of Point Counts for Surveying Cropland Birds. USDA Forest Service General Technical Report PSW-GTR-149, 69-74, Beltsville, Maryland, USA. 
González, C. (2000) Identificación de las áreas críticas para la conservación del Gorrión Serrano (Xenospiza baileyi). BA thesis, UNAM, México.

Haines-Young, R., Green, D. \& Cousins, S. (eds) (1993) Landscape Ecology and GIS. CRC Press, Gainesville, USA.

Haire, S., Bock, C., Cade, B. \& Bennet, B. (2000) The role of landscape and habitat characteristics in limiting abundance of grassland nesting songbirds in an urban open space. Landscape and Urban Planning, 48, 65-82.

Hill, M. O. (1979) Twinspan - A Fortran Program for Arranging Multivariate Data in an Ordered Two Way Table by Classification of the Individuals and the Attributes. Cornell University, Department of Ecology and Systematics, Ithaca, USA.

Hill, M. \& Gauch, H. (1980) Detrended correspondence analysis: an improved vegetation technique. Vegetatio, 42, 47-58.

Hood, G. (2003) Pop Tools, Version 2.5.4. Http/ / www. cse.csiro.au/poptools [accessed 23 June 2005].

Huff, M., Bettinger, K., Ferguson, H., Brown, M. \& Altman, B. (2000) A Habitat-based Point-count Protocol for Terrestrial Birds, Emphasizing Washington and Oregon. General Technical Report PNW-GTR-501. Department of Agriculture, Forest Service, Pacific Northwest Station. Portland, Oregon, USA.

Hutto, R., Pletschet, S. \& Hebdricks, P. (1986) A fixed-radius point count method for nonbreeding and breeding season use. The Auk, 103, 593-602.

IUCN (2004) IUCN Red List of Threatened Species. IUCN, Gland, Switzerland [http://www.redlist.org, accessed 10 October 2005].

Kull, C. (2002) Madagascar aflame: landscape burning as peasant protest, resistance, or resource management tool? Political Geography, 21, 927-953.

Lusk, J., Suedkamp, K., Guthery, F. \& Fuhlendorf, S. (2003) Lark sparrow (Chondestes grammacus) nest-site selection and success in a mixed-grass prairie. The Auk, 120, 120-129.

Mayr, R.M. (2000) Living together. Science, 288, 5464.

McCune, B. \& Mefford, M. (1995) PC-ORD, Multivariate Analysis of Ecological Data. Version 2.0. MjM Sofware Design, Gleneden Beach, USA.

Mooney, C. \& Duval, R. (1993) Bootstrapping: a Nonparametric Approach to Statistical Inference. Sage Publications, Newbury Park, USA.

Müeller-Dumbois, D. \& Ellenberg, H. (1974) Aims and Methods of Vegetation Ecology. Wiley, New York, USA.

Mukherjee, N. (1993) Participatory Rural Appraisal: Methodology and Applications. Concept Publishing Company, Delhi, India.

Oliveras de Ita, A., Gómez, H., de Silva, H. \& Grosselet, M. (2001) Population dynamics and natural history of the Sierra Madre sparrow Xenospiza baileyi at La Cima, México. Cotinga, 15, 43-47.

Pitelka, F. (1947) Taxonomy and distribution of the Mexican sparrow Xenospiza baileyi. Condor, 49, 199-203.

Roe, D. \& Elliot, J. (2004) Poverty reduction and biodiversity conservation: rebuilding the bridges. Oryx , 38, 137-139.
Rzedowski, J. (1978) Vegetación de México. Limusa, Mexico City, Mexico.

ter Braak, C. (1987) The analysis of vegetation-environment relationships by canonical correspondence analysis. Vegetatio, 69, 69-77.

Velázquez, A. (1993) Landscape Ecology of Tlaloc And Pelado Volcanoes, México. With Special Reference to the Volcano Rabbit (Romerolagus diazi), its Habitat, Ecology and Conservation. International Institute for Geo-Information Science and Earth Observation Publication 16, Amsterdam, Netherlands.

Velázquez, A., Bocco, G., Romero, F.J. \& Pérez-Vega, A. (2003) A landscape perspective to biodiversity conservation: the case of Central Mexico. Mountain Research and Development, 23, 240-246.

Velázquez, A. \& Heil, G. (1996) Habitat suitability study for the conservation of the volcano rabbit (Romerolagus diazi). Journal of Applied Ecology, 33, 543-554.

Velázquez, A. \& Romero, F. (eds) (1999) Biodiversidad de la región de montaña del sur de la Cuenca de México: bases para el ordenamiento ecológico. UAM Xochimilco-SEMARNAP, Mexico City, Mexico.

Wilson, R. \& Ceballos-Lascurain, H. (1993) The Birds of Mexico City. Second edition. BBC Printing and Graphics, Burlington, Canada.

\section{Appendix}

The Appendix for this article is available online at http:/ /journals.cambridge.org

\section{Biographical sketches}

Leonardo Cabrera-García has been studying birds in Mexico for more than 10 years and has now widened his research to include the examination of the effect of human social forces on changes in bird habitats. He is currently looking at the local practices and social institutions that influence the dynamics of the Sierra Madre sparrow's habitat, and developing a theoretical framework for community-based bird conservation.

Alejandro Velázquez carries out research on biodiversity conservation using the principles of landscape ecology. He is developing a research programme on co-management projects with indigenous communities in Central Mexico.

Martha Escamilla has previously carried out research on plant taxonomy and phytosociology in the mountain ecosystems of Central Mexico. She is currently a Project Evaluator at CONABIO. 